\title{
On Cultural Awareness in Middle School English Teaching
}

\author{
Zhang Li \\ School of Foreign Languages \\ Yanan University \\ Qinhuangdao, Hebei, China
}

\author{
Zhang Caiyun \\ School of Foreign Languages \\ Yanan University \\ Qinhuangdao, Hebei, China
}

\begin{abstract}
This paper focuses on enhancing students' ability of cross-cultural communication and their understanding of cultural differences especially in attitudes and values. Teachers can obtain the goal by providing cultural information, experiencing culture via role-plays, explaining culture with authentic materials and encouraging students to communicate with native English speakers. This article suggests that in middle school English teaching, teachers can provide a relaxed atmosphere for students to have an idea of the differences between their own culture and others' and explain the differences to strengthen students' cross-cultural awareness. It is expected that students can learn a second language not only from the aspect of grammar but of both language and culture.
\end{abstract}

Keywords-cultural awareness; difference; cross-cultural communication; English teaching

\section{RELATIONSHIP BETWEEN CULTURE AND LANGUAGE}

A language not only expresses facts, ideas, or events which represent similar world knowledge by its people, but also reflects the people's attitudes, beliefs, world outlooks, etc. However, culture is a wider system that includes language as a subsystem. They have very close relationship. "On the one hand, language as an integral part of human being permeates his thinking and way of viewing the world; language both expresses and embodies cultural reality. On the other hand, language, as a product of culture, helps perpetuate the culture, and the changes in language uses reflect the cultural changes in return. "[1]

Language and culture affect each other and cannot be separated. Culture is the root for a particular language to exist. If a second language learner has little knowledge about the cultural background, it will result in confusion, frustration and misunderstanding in cross-cultural communication. Culture is like the water and language is the fish. Language cannot exist without culture. For a second language learner, he will master the language only after knowing about the culture. Language and culture affect each other and cannot be separated. Culture is the root for a particular language to exist. If a second language learner has little knowledge about the cultural background, it will result in confusion, frustration and misunderstanding in cross-cultural communication. Culture is like the water and language is the fish. Language cannot exist without culture. For a second language learner, he will master the language only after knowing about the culture.

\section{THE SIGNIFICANCE OF FOSTERING STUDENTS' CULTURAL AWARENESS IN ENGLISH TEACHING.}

A Cultural awareness should be considered as a very important component in teaching a second language. One does not learn a language but acquires a language, and what one learns is not a language but the use of a language. In an English class, teachers should think about students' cultural awareness, attitude, creativity, and understanding, communicative competence and so on. Culture is an important property of language; language is a part of culture. One culture differs from all other cultures. When it comes to English teaching, it is very important to master cultures in English-speaking countries Teachers should make the differences between the two cultures clear; help students acquire English in a spontaneous way. Then students can communicate in the target language properly to achieve not only the linguistic competence, but also the communicative competence as well. That is of great significance in learning a foreign language.

Therefore, when learning a foreign language, students should not only learn the pronunciation, grammar, words and so on, but also learn to see the world as native speakers do. That is to say, students need to learn enough about the culture of the target language so that they can communicate with it properly to achieve not only the linguistic competence, but also the communicative competence as well. Otherwise the ignorance of cultural differences may create barriers in learning the second language, furthermore, cause the unnecessary misunderstanding and confusion.

\section{APPROACHES TO DEVELOPING STUDENTS' CULTURAL AWARENESS}

In the process of classroom teaching, it is up to teachers to raise students' cultural awareness and fully prepare them for culture learning. Meanwhile, the teacher should bear an open attitude towards foreign culture, share with students what he knows and present them in teaching and pay more attention to the cultural divergence when teaching.

For middle school students, the four basic skills (listening, speaking, reading and writing) are very important to learn English. Listening is the most difficult task for most students. It is the ability to identify and understand what others are saying. This involves understanding a speaker's accent, pronunciation, his grammar and vocabulary, and his underlined meaning. 
From the aspect of speaking, it is a matter of practice but not of theory. That is to say, the use of a language is more important than the usage of it. The aim of speaking is to communicate or to understand each other. Some students who have grasped many words and expressions cannot express themselves clearly. One most important reason is lack of cultural awareness. From the aspect of reading, it is a complex process of the interaction between the writer's language and the reader's prior background knowledge. Indeed, in the reading process, readers' capacities of reading are very important, but sometimes they cannot read between the lines, because the meaning of words will be acquired in a certain circumstance of culture. For writing, if one has no cultural knowledge of the target language, he cannot do it well. Therefore, as a middle school English teacher, one should expand students' cultural horizon and cultivate their cultural awareness.

\section{A. Providing Cultural Information}

To provide cultural information refers to the intention of informing students of cultural facts or drawing their attention to cultural comparison in brief, interesting, and easily accessible ways, such as a recording of a popular English song or a short tape-recording of English news items before the text explaining. It is also an effective and attractive way for students to learn English better if teachers encourage them to see classical fragments of English films, to listen to Special English programs of VOA and retell some in class to develop their pronunciation and intonation, and to pay much attention to the scene of western daily life and enlarge their knowledge about foreign culture. After two to three- months' studying with four or five times per week, students' listening and speaking comprehension skills will be improved together with teachers' explanation of cultural background information and they will decrease the puzzlement of foreign culture.

It is an effective and attractive way for middle school students to do these under the guidance of their teachers. It will create a colorful studying environment to develop students' interest of English learning. Meanwhile, teachers should give some advice and encourage students to insist on the plan. As language and culture combine together, Chinese students meet cross-cultural barriers from every aspect in the process of listening, watching and reading. However, it will reinforce these abilities.

\section{B. Experiencing Culture Via Role-Plays}

Arnold maintains that "it is helpful to discuss cultural differences and explain aspects of the target culture which might be problematic for foreign language learners"[2]. Roleplay is a helpful method to achieve this objective.

Well-designed and fully-conducted role-plays are an effective way to provide students with opportunity to experience authentic situations, and raise their awareness of communicative routines in the target culture. It creates real-life situations in the classroom by simulating everyday conversation, and encourages students to use the target language without much intervention from the teacher. In this way, it will enable students to take a more active part in the learning process. Using role-plays provides them with making use of the language they have learned, to share information, to act out difficult situations, to search for solutions, and to communicate feelings in a comparatively authentic environment. What's more, it helps illustrate the cultural differences in cross-cultural communication.

The use of carefully focused role-plays can enhance both understanding of the target language and skills in using and handling it appropriately. If scientifically designed, well organized and fully conducted role-play can be an effective technique in English teaching to raise students' awareness of the communicative routines in the target culture.

\section{Explaining Culture with Authentic Materials}

The term "authentic" has been used as a reaction against the artificial language of textbooks and instructional dialogues. Mass media, such as films, novels and especially newspapers and magazines, are considered as an insightful means for teaching culture, for they reflect people's way of life in terms of variety and authenticity. This material is by no means easy to interpret because there is so much basic differences and it requires deep familiarity and comprehensive explanation of culture. Therefore, all the materials should be selected in the process of language teaching. Teachers can also pick up some materials related to some aspects of culture revealed in newspapers and magazines and to the discussions of certain questions that might explain western patterns of behavior.

Besides, audio-visual media materials and approaches are so different from the traditional chalk and blackboard methods. It is widely welcome due to their vivid presentation of both language and cultural knowledge based on authentic circumstances. Using media in the teaching EFL in the classroom is certain to bring about a superior result. It helps to simplify the teaching and learning process and can help to perfect it. Moreover, it can bring in cultural input in a clear and realistic way as compared with traditional, media-free instruction.

To get students familiar with western culture, the teacher may create some situational contexts for students to experience the culture and know its difference in comparison with their own.

\section{Encouraging Students to Communicate with Native English Speakers}

The new era calls for students with the ability of crosscultural communication. People from different cultures have different communication styles. So a second language learner needs make clear about the similarities and differences of the two cultures when communicating with people from the target cultures. Middle school English teachers can also explain some ways and etiquette of greetings, addressing, responding to compliments and expressing one's own ideas, and most importantly, encourage students to communicate with foreigners. When talking with native speakers, the students will see a very different world. That means learning to see the world as native speakers of the language see it, learning the ways in which their language reflects the ideas, customs and behaviors of their society. Learning a language, in fact, is inseparable from learning its culture. 


\section{CONCLUSION}

Every language has its own culture. Language and culture have close relationship. "Culture should be our message to students and language our medium."[3] Culture teaching should increase students' knowledge of target culture in terms of life, value, attitude, and beliefs, and the teacher should be an expert in both mother culture and target culture. "It goes without saying that foreign language teachers should be foreign culture teachers, having the ability to experience and analyze both the home and target cultures." [4]

In such a multicultural society, it is a proper choice to learn different languages and cultures. When one communicates with people from other nations or cultural backgrounds, communication across cultures occurs. And meantime, teaching language would never fully succeed beyond teaching culture. If people communicate without knowing about the cultural background and social customs, it'll lead to great misunderstanding and embarrassment.

In conclusion, it is evident that culture has gained a significant role in foreign language learning. Only by learning the culture will we grasp the real language and the success of communication. While teaching the language knowledge, the teacher should transmit the information of different cultural background, local conditions, and social customs to students and make students aware of the importance of the cultural learning.

As an English teacher, it is essential and useful to acquire more knowledge of western cultural background and effective methodologies. Meanwhile, teachers should come up with new techniques to be a good one to improve students in English learning.

\section{REFERENCES}

[1] Dai Weidong and He Zhaoxiong, "A New Concise Course on Linguistics for Students of English", Shanghai: Shanghai Foreign Language Education Press, 2002, p.130.

[2] J. Arnold, "Affect in language learning", Cambridge: Cambridge University Press, 1999, p.268.

[3] D. Peck, "Teaching Culture: Beyond Language", Yale: New Haven Teachers Institute, 1998, p.268.

[4] M. Byram, "Teaching and Learning Language and Culture", Clevedon: United Kingdom Capstone Press, 1994, p.73. 